João José Reis and Flávio dos Santos Gomes, eds.

Freedom by a Thread: The History of Quilombos in Brazil. New York: Diasporic Africa Press, 2016. Pp. 534. Pb, \$24.99.

Originally published in 1996 as Liberdade por um fio: História dos quilombos no Brasil (São Paulo: Companhia das Letras), João José Reis and Flávio dos Santos Gomes's edited volume was quickly recognized as an important collection of essays in Brazil and by historians of Brazil living in North America and Europe. "Quilombo" (derived from the Kikongo term "kilombo") is a Portuguese term that denotes runaway settlements and the essays that appear in this book provide portraits of runaway communities that span both the colonial and early national periods of Brazilian history. Thus, the appearance of this volume in an English-language translation under the title Freedom by a Thread: The History of Quilombos in Brazil is a major occurrence for scholars of slavery and freedom working in the United States.

To date, much research on Brazilian quilombos has focused overwhelmingly on the quilombo of Palmares, a settlement that was founded in the present state of Alagoas, and that was famed in the seventeenth century for repeatedly defeating Portuguese and Dutch forces and for enduring for close to one hundred years. The first five essays of Reis and Gomes's volume focuses on Palmares, but the remainder of the book goes far beyond this case to examine histories of quilombos in other colonial provinces and contemporary states. Essays on Minas Gerais and Goiás in the eighteenth century, and essays on Rio de Janeiro, Bahia, Pernambuco, Mato Grosso, Rio Grande do Sul, Maranhão, and the Amazon in the nineteenth century comprise the other thirteen essays in this collection. Most of these essays endeavor to present quilombos as existing and thriving in close physical proximity to sites of slavery and through close working relationships with planters, merchants, and religious figures that upheld and defended the practice of slavery. This is a significant departure from many previous studies of quilombos that have emphasized the physical isolation of runaway communities and that have portrayed them as resistant to participating in the everyday workings of slave society.

Many of these essays advance bold, original claims centered on the way that quilombo activities shaped legislation and relations between different institutions of power. Silvia Hunold Lara's essay, for instance, argues convincingly that after the final destruction of Palmares in the late seventeenth century an increasing concern with preventing another Palmares led to the regulation of the post of "slave-catcher" in eighteenth-century Minas Gerais during Brazil's gold boom (1690-1750). Flavio dos Santos Gomes's essay takes us into what he 
refers to as the "black field" or "black encampment" of nineteenth-century Rio de Janeiro, an underground economy and social network that linked quilombos, merchants, planters, indigenous persons, and other non-elite members of society. Gomes demonstrates that some quilombos offered an alternative social community to those who resided within them, as well as forming part of an alternative trade circuit that many members of slave society benefitted from and defended. João José Reis's essay draws attention to the historical use of the term quilombo by examining a case in nineteenth century Bahia where white elites perhaps made a "juridical construction of a quilombo" for the purposes of repression. He bases this suggestion on the fact that the home base of one well-known quilombo was in fact a series lands owned by a wealthy farmer who negotiated with runaway slaves to work on his fields in exchange for protecting them from recapture.

For readers interested in the role that Jesuit missions occupied in histories of quilombos in Brazil, chapters four through six-each relating different aspects of the history of Palmares-will be of most interest. For instance, Ronaldo Vainfas's essay "God Against Palmares: Lordly Representations and Jesuitical Ideas" focuses on the theological question of slavery for Jesuit priests. Though the Jesuit missions indeed sanctioned and participated in slavery and plantation ownership in Brazil, in the late seventeenth century debates ensued around the enslavement of individuals who had been captured during warfare with Palmares in the 168 os. Some priests reasoned that since a number of these individuals had been born and lived as free people, they could not justly be enslaved. One eminent priest in Lisbon, Manuel Fernandes, was particularly ardent in this opinion. An Italian Jesuit, Giorgio ("Jorge") Benci, wrote a book blaming the proliferation of runaways that led to Palmares on master's treatments and even suggested that the Jesuits reach out to the quilombo to negotiate peace. Thus while famed Brazilian Jesuit priest António Vieira argued "no sacrament or doctrine for rebels," other high ranking members of the order strongly disagreed. While this essay focuses on religious missions and theology, it fits well within the volumes focus on how quilombo actions related to and shaped disputes within Brazilian institutions.

Jorge Benci's book and advice for how to treat slaves appears again in Silvia Hunold Lara's aforementioned essay. Luiz Mott's essay on Saint Anthony reveals António Vieira's admiration for the Franciscan saint, opening the possibility for further research that might provide more nuances to the longstanding historical characterization of Jesuits and Franciscans behaving antagonistically towards one another. Indeed, several authors often provide tantalizing suggestions that point towards new and future areas of inquiry into the relationship between quilombos and missionary practices. Luiza Rios Ricci Volpato's essay 
on quilombos in Mato Grosso, for example, references an instance where an expedition to conquer a quilombo ends with the quilombo members being recruited into the Christian faith and settled in something like a mission. Though this happened in the 1790s, one wonders how this late colonial phenomenon both built upon and departed from the earlier mission settlements of Jesuits and other orders.

There are moments in the book when it is not clear whether there were some mistakes in the process of translation, or whether these are simply mistakes that emerge from the process of printing the text. For example, in Vainfas's essay, this incomplete sentence appears at the end of a paragraph: "Palmares' final defeat and the death of legendary Zumbi in 1695." Moments like this surface throughout many of the essays and occasionally one has to slow down to get a sense of what is being communicated. Nevertheless, given the sort of research that could be developed by scholars who engage with this text, I reiterate that the very appearance of this work in an English-language translation is to be applauded and it should be an invaluable source of information on the history of quilombos in Brazil for some years to come.

\title{
Gregory Childs
}

\author{
Brandeis University \\ gchilds@brandeis.edu
}

DOI 10.1163/22141332-00404008-12 